\title{
Evaluation of Building Materials Based on Sustainable Development Indicators
}

\author{
Mona Baglou ${ }^{1}$, Parviz Ghoddousi ${ }^{1} \&$ Mohsen Saeedi ${ }^{1}$ \\ ${ }^{1}$ Civil Department, Iran University of Science and Technology, Tehran, Iran \\ Correspondence: Mona Baglou, Civil Department, Iran University of Science and Technology, Tehran, Iran. \\ E-mail: monabaglou@yahoo.com
}

Received: June 10, 2017

doi:10.5539/jsd.v10n4p143
Accepted: July 19, 2017 Online Published: July 30, 2017

URL: https://doi.org/10.5539/jsd.v10n4p143

\begin{abstract}
Construction industry regarded as one of the key aspects of achieving the goals of sustainable development in communities. In this regard, the choice of building materials is one of the key challenges in order to improve project performance with respect to sustainable development indicators and the use of sustainable materials, is an effective step towards achieving sustainable construction. This research uses information and evidence, interview and questionnaire prepared (by five points Likert scale method). Also, it has provided expert opinions related indicators widely used in a construction materials, manufacturing process and defining the impact of the production of these materials on sustainable development deals. Validity and reliability of the questionnaires were also performed (with Cronbach's alpha method). As a result of this research, Cement was identified as the most unsustainable material, after that Steel and then Brick and Glass were located with a wide margin. So Light concrete block, Gypsum, Stone, Lime, and Concrete were identified as the most sustainable materials according to existing indicators respectively. The consequences of this study can help the project executors in order to promote the use of sustainable building materials in construction and also industries will be aware of the impact of the sustainability indicators on their products.
\end{abstract}

Keywords: sustainable development, sustainable construction, building materials, sustainable materials, indicator

\section{Introduction}

Population growth and technological progress, problems such as the progressive destruction of resources, lack of water, followed by global warming is created. So that this becomes a problem of global concern, and that is why sustainable development is now known as the greatest challenge of the 21 st century. In this regard, the World Commission on Environment and Development, entitled "Our Common Future" on sustainable development in 1987, a report prepared for all nations that sign of growing concern to protect the environment and resources for future generations. In addition, the United Nations Conference on Environment and Development in 1972, Agenda 21 and the Rio Conference in 1992, indicating the importance of sustainable development in today's society.

In addition, in recent decades, more than ever, the construction industry associated with improving the social, economic and environmental aspects. According to the CIB in 1998, 54\% of the energy consumed in America directly and indirectly related to the construction industry in Europe the figure is $40 \%$ of total energy consumption. The MOC-1999 report also stated that about 25 percent of China's energy consumption in the process of building and construction. The environmental effects of Construction industry is really high so that it is allocated about $40 \%$ of raw material's extraction, $70 \%$ of power consumption and $12 \%$ of drinkable water in industrial countries. Also, three billion tons of raw materials for production of building materials are being used annually throughout the world. In addition, the industry is responsible for a third of global $\mathrm{CO}_{2}$ emissions, according to the Kyoto Protocol, Europe is committed to reducing greenhouse gas emissions by $8 \%$ compared to its level in 1990. Furthermore, the construction industry includes 40 to 50 percent of the entire global economy and with a share of 5.7 percent as the largest employment sector in Europe. In addition, $11 \%$ of the share of construction in GDP is the role of industry in economic terms. In addition to the process of global population growth from 5.6 billion in 2005 to around 9 billion in 2035. Therefore, the importance of sustainable development in construction projects seems to be essential. And society requires a new project in order to fulfill 
the economic, social and environmental. Given that building has a significant role in increasing environmental impacts, particularly in carbon emissions rate, the process of "green building" presents to reduce these effects and improve the appearance, but the question that arises is "what the criteria of green building or sustainable is? " This question has been a constant challenge to the scientific community who has made several comments. Although new technologies are constantly created to complement current practices in developing green buildings, the common goal of all the methods of reducing the overall environmental impact in the following areas: Energy efficiency and renewable energy, Water Efficiency, Building Materials, Construction waste reduction, Reduce toxins, indoor air quality, smart growth and sustainable development and Eco-friendly materials. In fact, to move toward green building in order to protect non-renewable natural resources, protecting the environment, saving energy and reducing costs, the first step is modifying ordinary building materials to sustainable one. Sustainable building materials should be appropriate for local use also reduce carbon emissions and conserve natural resources, reduce production costs and prepare a suitable occasion for employment.

Chen and Chambers in 1999 convinced that sustainable construction in China spends its early stages, due to the economic slowdown in China's economic development was useful for the growth and overcoming poverty. They examined the measures taken in China engaged in the field of sustainable and the policies in the field of sustainable construction in China has been adopted, the lack of systematic implementation of the policies cited and expressed serious concern about the environmental problems in China's projects. They introduced a lack of awareness as one of these issues and believed sustainable development as a major step forward in improving the environment for economic growth.

Li-yin Shen et al, had a study in 2010 on the construction projects in China, infrastructure projects are considered a good way to achieve sustainable development and to seek a balance between economic performance, social, environmental construction projects considered important. Feasibility study for a new approach was introduced to the principles of sustainable development. During their research the feasibility studies in China, the economic performance of greater concern to projects and less attention to the environmental performance of the barriers to sustainable construction.

Yasantha and Sandara, did a research on the sustainability of construction materials and they investigated different construction materials' life-cycle and present a final score of each aspect of sustainability indicators in environment, economy, and society for materials. Indicators examined in this study were about the reduction of the greenhouse effect, acid rain, cost and usability were quick to emphasize. Eventually, after the analysis of materials used in different parts of the building, wood as superior materials was selected for sustainability based on their research.

Despite lots of research has been done about identifying and evaluation of sustainability indicators, these results are mostly based on rating systems, but the problem is that these systems cannot be used for all buildings since regional conditions and construction technologies are different so materials which are used in these areas are completely different. Obviously, the evaluation and selection of materials has a particular importance and using sustainable materials is one of the ways to achieve sustainable construction. Namely, by taking all three dimensions of sustainability and focusing on environmental issues.

Considering that manufacturing process is highly important and the most destructive Due to none of the previous studies assess the sustainability of the building materials according to indicators related to the manufacturing process, this study used previous studies and expert opinions based on five-point Likert scale method and data analysis, while providing indicators related to the production process widely used in construction materials, pays this aspect: whether the production of these materials according to the sustainable development indicators appropriate.

\section{Material and Methods}

This study examines the construction materials on the basis of sustainable development indicators so calibration is used with quantitative data, documentaries. Based on the derived data, an industry questionnaire survey was designed to investigate the perspective of construction professionals on the importance of the indicators. Thirty two experts comprising of Civil Engineers ,Industrial Engineers ,Environment Engineers and Architect Engineer that influence material selection were thus asked to rate the level of importance of the indicators based on a scale of 1-5 which is known as Likert Scale, where 1 is 'least important', 2 'fairly important', 3 'important', 4 'very important', and 5 'extremely important'. The adequacy of information depends on the reliability of the data collected from the questionnaire, Reliability is concerned with the consistency of our measurement. Cronbach's alpha coefficient which has been widely used for reliability testing, was employed in this study to ensure the reliability of the survey (Eq.1). Also In order to achieve the adequacy before survey designing, the indicators 
related to sustainability in building materials production were obtained by 4 experts: A Construction management professor, An Environment engineering professor and two $\mathrm{PhD}$ students who had studied on this subject. So the ability to understand and validity of the questionnaires was acceptable.

$$
\alpha=\frac{\mathrm{k}}{\mathrm{k}-1}\left(1-\frac{\sum_{\mathrm{i}=1}^{\mathrm{k}} \mathrm{Si}^{2}}{\sigma^{2}}\right)
$$

Where K: Number of questions (indicators), Si2: Variance of responses to each indicator, $\sigma^{2}$ : Variance of sum of each respondent answers for all indicators, The level of results reliability for different Cronbach's alpha ranges is shown in Table 1 according to Liyin shen (2011), in common an alpha coefficient higher than 0.7 is reliable.

Table 1. Cronbach's alpha ranges

\begin{tabular}{cc}
\hline Cronbach's alpha coefficient & Reliability \\
\hline$\alpha \geq 0.9$ & Excellent \\
$0.7 \geq \alpha>0.9$ & Good \\
$0.6 \geq \alpha>0.7$ & Acceptable \\
$0.5 \geq \alpha>0.6$ & Poor \\
$\alpha<0.5$ & Unacceptable \\
\hline
\end{tabular}

In the first step, materials based on sustainability indicators related to several articles that have been published in recent years through meetings identify and brainstorming seminars and techniques were provided a list of 100 indicators. Then for choosing the most important indicators of sustainability with a focus on the production of building materials and indicators which have available quantitative, 25 indicators of the first step were chosen to assess the experts.

Relative index analysis was selected in this study to rank the indicators according to their relative importance. The Eq. 2 is used to determine the relative index (RI):

$$
\mathrm{RI}=\sum \frac{\mathrm{W}}{\mathrm{A}} * \mathrm{~N}
$$

Where RI (Relative index) is used for ranking indicators (degree of importance). $\mathrm{W}$ is the weighting as assigned by each respondent on a scale of one to five with one implying the least and five the highest. A is the highest weight (i.e. 5 in our case) and $\mathrm{N}$ is the total number of the sample. Five important levels are transformed from Relative Index values: High (H) $(0.8 \leq \mathrm{RI} \leq 1)$, High-Medium $(\mathrm{H}-\mathrm{M})(0.6 \leq \mathrm{R}<0.8)$, Medium (M) $(0.4 \leq \mathrm{R}<0.6)$, Medium-Low (M-L) $(0.2 \leq \mathrm{R}<0.4)$, and Low (L) $(0 \leq \mathrm{R}<0.2)$.

In step three, after reviewing the materials widely used in construction, another questionnaire was designed on the impact of each indicator in the production of materials and the experts were answered it and the results were analyzed, also based on the quantitative data from final indicators in step two and analysis, the final score of each material based on sustainable development was achieved. For gaining data and information for final indicators, documentaries and library references were used also in this research, static analysis was performed by Microsoft Excel 2010.

In this step firstly, all results gained from references and quantitative data for materials, after Unit Conversion, were gathered into a matrix. The maximum value of each index was considered to be 1 and other values were get rated based on it, so coefficient matrix for materials was created. Also weight scored matrix for materials was created with Conversion of obtained rates from experts answers to weight percentage. Having these two tables, the final scores of materials were obtained from the total weight coefficients of each of the first matrix cells in the same cell in the second table. So, to determine at what level the score obtained in terms of sustainability, requires an average score and the score sustainability threshold which they obtained from the sum of averages of each column in the weight matrix. The material which is above the average is not ideal based on sustainability and the ones sustainability threshold is unsustainable.

\section{Results and Discussion}

\subsection{Summary of Respondents Demographic Data}

In this research 32 experts have participated from different majors based on the subject of the study. Some of the 
respondents had answered both questionnaires. The first questionnaire was sent to 56 respondents. Twenty two questionnaires were sent back after filling. So the feedback coefficient of this questionnaire was 40 percent as a result and was acceptable. Then the experts who had responded to the first questionnaire were asked to answer the second questionnaire. Also 11 other experts who were related to material production in Iran were chosen to fill the second questionnaire. Finally 19 of 32 questionnaires were responded and were sent back and feedback coefficient of the second questionnaire was 60 percent and acceptable. Table 2 shows Summary of respondent's demographic data.

Table 2. Summary of respondents' demographic data

\begin{tabular}{|c|c|}
\hline \multicolumn{2}{|c|}{ Panel 1:Academic Qualification } \\
\hline First Degree & $2(6.25 \%)$ \\
\hline Masters Degree & $14(43.75 \%)$ \\
\hline PhD & $16(50 \%)$ \\
\hline Total & $32(100 \%)$ \\
\hline \multicolumn{2}{|c|}{ Panel 2:Professional Qualification } \\
\hline Civil Engineer & $23(73 \%)$ \\
\hline Industrial Engineer & $16(5 \%)$ \\
\hline Environment Engineer & $9(3 \%)$ \\
\hline Architect Engineer & $3(1 \%)$ \\
\hline Total & $32(100 \%)$ \\
\hline \multicolumn{2}{|c|}{ Panel 3:Work Experience } \\
\hline Under 5 years & $2(6.25 \%)$ \\
\hline 5-10 years & $6(18.75 \%)$ \\
\hline $10-15$ years & $8(25 \%)$ \\
\hline $15-20$ years & $7(21.875 \%)$ \\
\hline 20-25 years & $4(12.50 \%)$ \\
\hline $25-30$ years & $2(6.25 \%)$ \\
\hline Over 30 years & $3(9.375 \%)$ \\
\hline Total & $32(100 \%)$ \\
\hline
\end{tabular}

\subsection{Identifying Sustainability Indicators}

In this step, the most effective and the most important indicators in materials production were defined after analyzing the first questionnaire and they were check for their degree of importance based on( formula 1 and table 1). Finally 9 indicators were chosen from the list of 25 indicators and they were used to the end of the research. Table 3 shows the result of ranking these indicators. 
Table 3. Final ranking effective factors in the production of building materials

\begin{tabular}{|c|c|c|c|c|c|}
\hline No. & Effective Factor & $\begin{array}{c}\text { Weight } \\
\text { percentage }\end{array}$ & $\begin{array}{c}\text { Importance } \\
\text { Average } \\
(1-5)\end{array}$ & $\begin{array}{l}\text { Relative } \\
\text { index(RI) }\end{array}$ & $\begin{array}{c}\text { Standard } \\
\text { deviation(SD) }\end{array}$ \\
\hline 1 & Production Cost & 0.864 & 4.32 & $\mathrm{H}^{*}$ & 0.71 \\
\hline 2 & Raw material Consumption & 0.846 & 4.23 & $\mathrm{H}$ & 0.75 \\
\hline 3 & Fuel Consumption & 0.836 & 4.18 & $\mathrm{H}$ & 0.96 \\
\hline 4 & Electricity(power) Consumption & 0.826 & 4.13 & $\mathrm{H}$ & 1.03 \\
\hline 5 & Green House Effect & 0.818 & 4.09 & $\mathrm{H}$ & 0.81 \\
\hline 6 & Water Consumption & 0.790 & 3.95 & $\mathrm{M}^{*}-\mathrm{H}$ & 0.95 \\
\hline 7 & Employment & 0.762 & 3.81 & M-H & 1.05 \\
\hline 8 & Production Rate & 0.744 & 3.72 & M-H & 0.59 \\
\hline 9 & Non-Green House Effect & 0.680 & 3.40 & M-H & 0.82 \\
\hline 10 & Quality Control & 0.590 & 2.95 & M & 1.17 \\
\hline 11 & Economy Growth & 0.554 & 2.77 & M & 1.02 \\
\hline 12 & Work Accidents & 0.544 & 2.72 & M & 1.10 \\
\hline 13 & Worker's Experience & 0.526 & 2.63 & M & 1.21 \\
\hline 14 & Labor costs & 0.518 & 2.59 & M & 1.05 \\
\hline 15 & The use of recyclable materials & 0.498 & 2.49 & M & 1.44 \\
\hline 16 & Production Waste & 0.480 & 2.40 & M & 1.81 \\
\hline 17 & Soil Pollution & 0.478 & 2.39 & M & 0.90 \\
\hline 18 & The use of local resources & 0.472 & 2.36 & M & 1.04 \\
\hline 19 & Export & 0.454 & 2.27 & M & 1.02 \\
\hline 20 & Indoor air pollution & 0.444 & 2.22 & M & 1.06 \\
\hline 21 & Health and welfare of workers & 0.436 & 2.18 & M & 1.01 \\
\hline 22 & local development aspect & 0.426 & 2.13 & M & 1.22 \\
\hline 23 & Workers Performance & 0.418 & 2.09 & M & 0.83 \\
\hline 24 & Climate Change & 0.380 & 1.90 & $M-L^{*}$ & 0.70 \\
\hline 25 & Sound Pollution & 0.344 & 1.72 & M-L & 0.86 \\
\hline
\end{tabular}

* H: high, M: medium, L: low

The average of responders was 3.29 from 5 so as it is clear the nine defined indicators (e.g. Production Cost, Raw Material Consumption, Fuel Consumption, Electricity Consumption, Green House Effect, Water Consumption, Employment, Production Rate and Non-Green House Effect) have values more than average also their relative index(RI) are High or Medium to High $(\mathrm{M}-\mathrm{H})$. Considering that Cronbach's alpha coefficient of the questionnaire was 0.766, so questionnaire is reliable and acceptable. As table 2, The indicators "Fuel consumption " and "electricity consumption" were almost equal, in the next questionnaire these two index were complete together and called : "energy consumption".

\subsection{Effect of Obtained Indicators in Construction Materials Production}

In this step, mentioning the finalized indicators from the previous step, the common and useful building materials in construction based on documentaries and available articles which were mentioned before. Also, considering that which one is more challenging for sustainable development they were chosen. After extraction quantitative data from them, their units were converted to compare much more comfortable. An important tip is that in some materials there were more than one data so the data which was from a more reliable reference was chosen and in some indicators which there was no exact data, it obtained from some math calculations like interpolating for the assimilating data. Table 4 shows quantitative data gained from references. 
Table 4. Materials data

\begin{tabular}{|c|c|c|c|c|c|c|c|c|c|c|}
\hline Materials & $\begin{array}{c}\mathrm{CO}_{2} \\
(\mathrm{~kg} / \text { ton })^{1}\end{array}$ & Ref. & $\begin{array}{c}\text { Fuel } \\
(\mathrm{kg} / \text { ton })^{2}\end{array}$ & Ref. & $\begin{array}{c}\text { Power } \\
(\mathrm{kwh} / \mathrm{ton})^{2}\end{array}$ & Ref. & $\begin{array}{c}\text { Water } \\
(\text { Liter/ton })^{3}\end{array}$ & Ref. & $\begin{array}{c}\text { Raw } \\
(\mathrm{kg} / \text { ton })^{4}\end{array}$ & Ref. \\
\hline Cement & 927 & {$[20]$} & 5.85 & {$[25],[26]$} & 110 & {$[25],[26]$} & 343 & {$[20]$} & 1600 & [24] \\
\hline Steel & 1800 & {$[21]$} & 2.14 & [27] & 112 & [27] & 5330 & {$[21]$} & 1900 & [21] \\
\hline Concrete & 220 & [19] & 1.6 & {$[28],[29]$} & 45 & {$[28],[29]$} & 284 & {$[20]$} & 880 & [38] \\
\hline Brick & 140 & [18] & 6 & [30] & 100 & [30] & 700 & [34] & 1100 & [39] \\
\hline Gypsum & 70 & {$[16]$} & 1.2 & [31] & 15.22 & [31] & 580 & [35] & 1200 & [35] \\
\hline Lime & 440 & [22] & 6.2 & [32] & 35 & [32] & 400 & {$[36]$} & 1500 & [36] \\
\hline CLC & 163.5 & [17] & 1.2 & [28] & 1.05 & [28] & 126 & [17] & 420 & [40] \\
\hline Stone & 330 & [23] & 1.5 & [28] & 100 & [28] & 907 & [37] & 1350 & [37] \\
\hline Glass & 570 & {$[24]$} & 7.8 & {$[24],[33]$} & 97.5 & {$[24],[33]$} & 150 & {$[24]$} & 1700 & [24] \\
\hline
\end{tabular}

Table4. Materials data (continue)

\begin{tabular}{ccccccccccc}
\hline Materials & $\begin{array}{c}\mathrm{SO}_{2} \\
(\mathrm{~kg} / \mathrm{ton})^{5}\end{array}$ & Ref. & $\begin{array}{c}\mathrm{NOx} \\
(\mathrm{kg} / \text { ton })_{5}\end{array}$ & Ref. & $\begin{array}{c}\text { Employment } \\
(\text { Person/year })_{6}\end{array}$ & $\begin{array}{c}\text { Ref. } \\
\text { cost } \\
(\text { Dollars/ton })_{7}\end{array}$ & $\begin{array}{c}\text { production } \\
\text { rate } \\
\text { Ref. }\end{array}$ & $\begin{array}{c}\text { Ref. } \\
(\text { Ton/year })_{7}\end{array}$ \\
\hline Cement & 0.53 & {$[41]$} & 3.65 & {$[41]$} & 40000 & {$[48]$} & 6 & {$[52]$} & 77000000 & {$[55]$} \\
Steel & 0.045 & {$[42]$} & 0.04 & {$[42]$} & 30000 & {$[49]$} & 14 & {$[53]$} & 17000000 & {$[55]$} \\
Concrete & 0.0036 & {$[43]$} & 0.0021 & {$[43]$} & 31500 & {$[50]$} & 16 & {$[54]$} & 45000000 & {$[55]$} \\
Brick & 2.5 & {$[18]$} & 0.16 & {$[18]$} & 30000 & {$[39]$} & 2 & {$[52]$} & 50000000 & {$[55]$} \\
Gypsum & 0.027 & {$[44]$} & 0.13 & {$[44]$} & 116500 & {$[35]$} & 4 & {$[35]$} & 30000000 & {$[55]$} \\
Lime & 2.7 & {$[45]$} & 1.6 & {$[45]$} & 250 & {$[36]$} & 6.2 & {$[36]$} & 60000 & {$[55]$} \\
CLC & 0.45 & {$[40]$} & 0.00126 & {$[40]$} & 5000 & {$[40]$} & 10 & {$[17],[40]$} & 720000 & {$[55]$} \\
Stone & 0.44 & {$[46]$} & 0.54 & {$[46]$} & 63500 & {$[51]$} & 5.7 & {$[51]$} & 120000000 & {$[55]$} \\
Glass & 1.7 & {$[47]$} & 3.1 & {$[47]$} & 1200 & {$[48]$} & 9 & {$[24]$} & 900000 & {$[55]$} \\
\hline
\end{tabular}

As it has been seen in Table 4, steel industry dedicated the first place in $\mathrm{CO}_{2}$ emission and in this context makes a lot of harm effects on the environment. After that Cement production emitted a large amount of $\mathrm{CO}_{2}$ and the rest of the industry are located by a wide margin. Considering the different manufacturing process, in this research fuel and power consumption factors are obtained from "Energy balance sheet" of Iran that for great comparing, all the units came to a same one. As this table displays, the fuel consumption in the flat glass manufacturers accounted for first place, after that lime, brick, cement and another materials by a wide margin. It should be noted that in the data related to energy (power and fuel), Energy balance sheet and relevant standards had been a priority. Considering that manufacturing process are different and we are not completely acknowledged about the kind of process when we are using the materials, so the average of total available processes was considered. The water consumption in steel industries are absolutely high and it is because of its production process that need High-pressure water pumps in a large amount. This value which is set in table 5 is related to consumption in Isfahan Steel company in Iran which it is mostly optimum. However, unfortunately in some other companies this value is 18 to $22 \mathrm{~m}^{3}$ per ton. The raw materials' consumption vales are the sources of raw materials that are naturally derived and extracted. In this part, Steel has the first place of raw material consumption, after that glass, cement and other materials are placed.

Non-greenhouse gases and especially $\mathrm{SO}_{2}, \mathrm{NOx}$ which are the main factors of producing acid rains are so harmful for the environment, too. Which Cement is the most producer of $\mathrm{SO}_{2}$ and Lime is the most responsible material for producing NOx. The direct employment was considered so that it depends on production part. The annually Cement production has the most employment rate comparing other materials. After that, Steel took place. By the way, Concrete and Brick have mostly the same values. 
The production cost of cement is much priceless than steel and concrete and it is the reason of why the production rate of this material is more than others. The most production cost rate per ton is related to Concrete and Steel is in second place and after that light concrete block and glass and other materials. Considering that environmental indicators in cement are much higher than other materials, producing of this material causes harmful effects on the environment. As the values show, the annual production rate of this materials is more than others and just about 17 tons of Cement production in Iran are exported each year. However, 60 ton of produced cement are being used annually in a construction project in Country, which this is worrying in terms of public health.

\subsection{Scoring Criteria for Production of Each Building Material}

The results were adjusted in a matrix. The Cronbach's alpha coefficient of the questionnaire was 0.848 so the results are valid and acceptable. The general significance of respondents to each of the materials according to all indicators in Table 5 displays the mean and standard deviation units. As specified, cement and then steel have the greatest significance, in other words, the most challenging materials with regard to sustainable development.

Table 5. Mean and standard deviation of respondents

\begin{tabular}{|c|c|c|c|c|c|c|c|c|c|}
\hline Indicators & Society & Eco & omy & & & Environment & & & \\
\hline indicators &  & 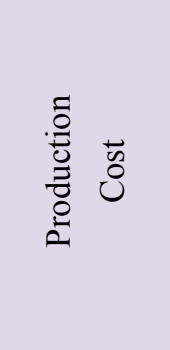 &  & 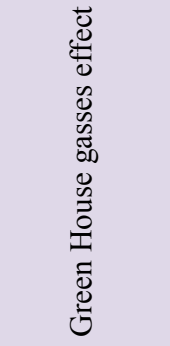 & 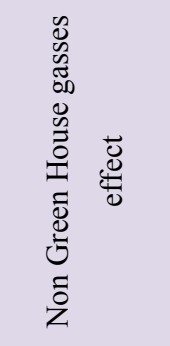 & 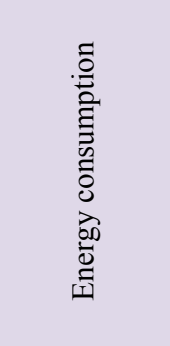 & 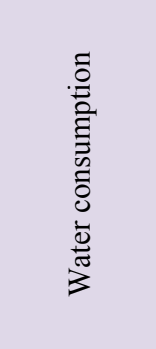 & 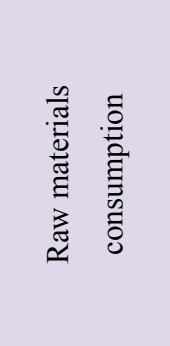 & 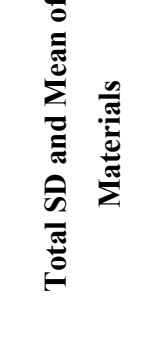 \\
\hline Cement & $(3.35,1.22)^{*}$ & $(3.90,0.96)$ & $(3.60,1.09)$ & $(3.85,0.81)$ & $(3.45,0.82)$ & $(4.30,0.86)$ & $(3.75,1.16)$ & $(3.55,1.10)$ & $(3.71,1.03)$ \\
\hline Concrete & $(3.05,1.08)$ & $(3.47,1.07)$ & $(3.42,1.90)$ & $(2.89,0.8)$ & $(2.42,0.69)$ & $(3.26,0.93)$ & $(3.36,0.83)$ & $(3.21,1.18)$ & $(3.38,1.12)$ \\
\hline Steel & $(3.26,0.93)$ & $(3.79,1.13)$ & $(3.68,0.95)$ & $(3.26,1.14)$ & $(2.52,0.96)$ & $(4.05,1.07)$ & $(3.63,1.25)$ & $(3.21,1.03)$ & $(3.13,0.98)$ \\
\hline Brick & $(2.94,1.13)$ & $(3.21,0.91)$ & $(2.73,0.99)$ & $(2.79,1.18)$ & $(2.21,1.03)$ & $(3.52,0.90)$ & $(3.10,1.24)$ & $(3.00,1.05)$ & $(2.94,1.09)$ \\
\hline Gypsum & $(2.89,0.93)$ & $(3.21,1.03)$ & $(3.32,0.74)$ & $(2.63,1.06)$ & $(2.31,1.00)$ & $(3.42,1.01)$ & $(2.73,1.04)$ & $(2.57,1.42)$ & $(2.88,1.08)$ \\
\hline Lime & $(2.47,0.9)$ & $(2.94,1.12)$ & $(3.31,0.94)$ & $(2.73,0.73)$ & $(2.26,0.93)$ & $(2.84,0.95)$ & $(2.89,0.99)$ & $(2.89,1.22)$ & $(2.78,1.00)$ \\
\hline $\begin{array}{l}\text { Light weight } \\
\text { Concrete }\end{array}$ & $(2.73,0.65)$ & $(3.52,1.02)$ & $(3.36,1.06)$ & $(2.63,0.95)$ & $(2.21,0.78)$ & $(2.94,1.02)$ & $(2.78,1.08)$ & $(2.68,0.94)$ & $(2.86,1.00)$ \\
\hline Stone & $(2.63,0.95)$ & $(3.05,1.07)$ & $(3.10,0.87)$ & $(2.42,1.01)$ & $(1.84,0.68)$ & $(2.89,1.24)$ & $(2.63,1.11)$ & $(2.84,1.42)$ & $(2.67,1.10)$ \\
\hline Glass & $(2.84,0.76)$ & $(3.10,0.81)$ & $(3.31,0.75)$ & $(2.47,0.90)$ & $(2.05,0.84)$ & $(3.36,0.83)$ & $(2.79,0.91)$ & $(2.31,0.94)$ & $(2.78,0.93)$ \\
\hline
\end{tabular}

\subsection{Obtaining Final Materials Grade Based on Sustainable Development Indicators}

In preparing the questionnaire 2 consumption index of fuel and power were merged to energy consumption index. Also effect of non-greenhouse was divided to two gasses: $\mathrm{NOx}$ and $\mathrm{SO}_{2}$. So results were obtained in a matrix based on step three of the research process as we talk about before. Table 6 shows these results and other results placed in a weight rated matrix as it is shown in Table 7. Having the consequences of these two tables and reviewing step three of research process the final score of each material was obtained. Table 8 displays the final results of these research. 
Table 6. Coefficients indicators matrix on materials

\begin{tabular}{|c|c|c|c|c|c|c|c|c|c|c|}
\hline Indicators & 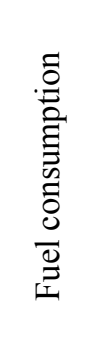 & 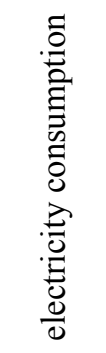 & 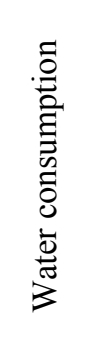 & 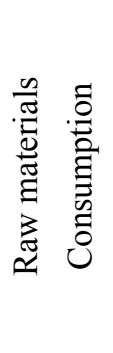 & ঠి & 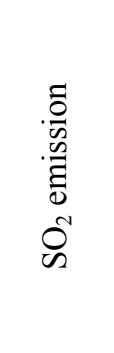 & 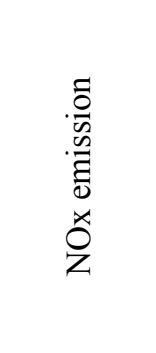 &  & $\begin{array}{l}\overrightarrow{0} \\
0 \\
0 \\
0 \\
0 \\
0 \\
0 \\
0 \\
0\end{array}$ & 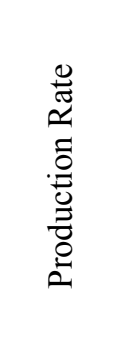 \\
\hline Cement & 0.75 & 0.98 & 0.06 & 0.84 & 0.51 & 0.19 & 1.00 & 1.00 & 0.37 & 1.00 \\
\hline Concrete & 0.27 & 1.00 & 1.00 & 1.00 & 1.00 & 0.02 & 0.01 & 0.75 & 0.87 & 0.22 \\
\hline Steel & 0.20 & 0.40 & 0.05 & 0.46 & 0.12 & 0.001 & 0.0005 & 0.787 & 1.00 & 0.58 \\
\hline Brick & 0.76 & 0.89 & 0.13 & 0.57 & 0.07 & 0.92 & 0.004 & 0.75 & 0.125 & 0.64 \\
\hline Gypsum & 0.15 & 0.135 & 0.10 & 0.63 & 0.038 & 0.01 & 0.035 & 0.312 & 0.25 & 0.38 \\
\hline Lime & 0.79 & 0.312 & 0.07 & 0.78 & 0.24 & 1.00 & 0.43 & 0.00625 & 0.38 & 0.0007 \\
\hline $\begin{array}{l}\text { Light weight } \\
\text { Concrete }\end{array}$ & 0.15 & 0.01 & 0.02 & 0.22 & 0.09 & 0.16 & 0.000049 & 0.125 & 0.63 & 0.009 \\
\hline Stone & 0.19 & 0.89 & 0.17 & 0.71 & 0.18 & 0.162 & 0.27 & 0.50 & 0.35 & 0.15 \\
\hline Glass & 1.00 & 0.87 & 0.02 & 0.89 & 0.316 & 0.62 & 0.84 & 0.03 & 0.56 & 0.011 \\
\hline
\end{tabular}

Table 7. Rated weight indicators matrix on materials

\begin{tabular}{|c|c|c|c|c|c|c|c|c|}
\hline indicators & 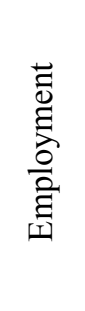 &  & 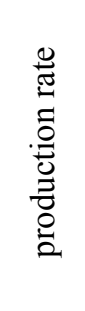 & 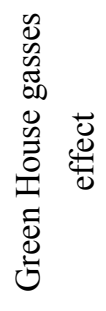 & 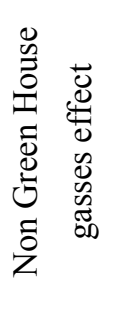 & 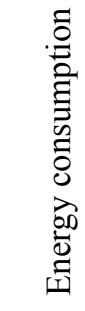 & 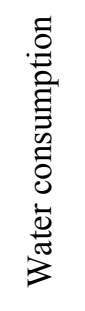 & 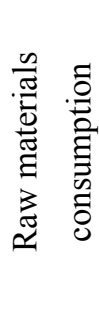 \\
\hline Cement & 0.67 & 0.78 & 0.72 & 0.77 & 0.69 & 0.86 & 0.75 & 0.71 \\
\hline Concrete & 0.61 & 0.69 & 0.68 & 0.57 & 0.48 & 0.65 & 0.67 & 0.64 \\
\hline Steel & 0.65 & 0.75 & 0.73 & 0.65 & 0.50 & 0.81 & 0.72 & 0.64 \\
\hline Brick & 0.58 & 0.64 & 0.54 & 0.55 & 0.44 & 0.70 & 0.62 & 0.60 \\
\hline Gypsum & 0.57 & 0.64 & 0.65 & 0.52 & 0.46 & 0.68 & 0.54 & 0.51 \\
\hline Lime & 0.49 & 0.59 & 0.66 & 0.54 & 0.45 & 0.56 & 0.58 & 0.57 \\
\hline $\begin{array}{l}\text { Light weight } \\
\text { Concrete }\end{array}$ & 0.54 & 0.70 & 0.67 & 0.52 & 0.44 & 0.59 & 0.55 & 0.53 \\
\hline Stone & 0.53 & 0.61 & 0.62 & 0.48 & 0.36 & 0.58 & 0.53 & 0.56 \\
\hline Glass & 0.57 & 0.62 & 0.66 & 0.49 & 0.41 & 0.67 & 0.56 & 0.46 \\
\hline Mean & 0.58 & 0.66 & 0.65 & 0.56 & 0.47 & 0.68 & 0.61 & 0.58 \\
\hline
\end{tabular}


Table 8 . Rate of materials based on sustainability indicators

\begin{tabular}{cccccccccc}
\hline Material & Cement & Concrete & Steel & Brick & Gypsum & Lime & Light weight concrete & Stone & Glass \\
\hline Final Score & $5.02^{*}$ & 2.35 & 4.37 & 2.90 & 1.11 & 2.10 & 0.85 & 1.93 & 2.80 \\
Rate & 9 & 5 & 8 & 7 & 2 & 4 & 1 & 3 & 6 \\
\hline
\end{tabular}

Sustainability threshold $=4.79$ (Total average for each column of the matrix) $\&$ Average range $=2.40$

*Ex:

Cement Score $=$

$0.86(0.75+0.98)+(0.06 \times 0.75)+(0.84 \times 0.71)+(0.51 \times 0.77)+$

$0.69(0.19+1)+(1 \times 0.67)+(0.37 \times 0.78)+(1 \times 0.72)=5.02$

\section{Conclusion}

In this study, in one hand sustainability of building materials were obtained. So Cement and Steel were identified as the most unsustainable materials and then and then by large margins brick and glass were took place and Light concrete block, Gypsum, Stone, Lime and Concrete were identified as sustainable (Green) building materials respectively. On the other hand, nine indicators were obtained as the most important factors based on expert's opinions (Inclusive Production Cost, Raw materials consumption, Fuel consumption, Power Consumption, Green House gasses effect, Water consumption, Employment, Production rate and Non-Green House gasses effect). The obtained values and data were related to materials production in Iran and the results could be different in other countries based on their technologies and productions.

Generally, employment as a social indicator has a great importance in the communities, especially in developing countries. About Economy, if there is no environmental problems and pollution from factories, the large amount of production will be helpful and contribute to economic growth and can also be an effective step forward in the field of exports. Considering that Cement was identified as an unsustainable material it cause harmful effects on the environment. However, it is not possible to stop all the cement production in factories so that it is the main ingredient in some other productions like concrete and block industry. The main problem is about production process which is widely used without any changes in decades. So changing the production process like adding Pozzolan, Stone powder, Slag and other alternatives to clinker, can improve the sustainability of this product, based on previous researches.

Furthermore, about steel production, some changes about reforming pattern of Water consumption will be helpful as other researchers investigated before. In addition, considering that light concrete block as a new construction technology, was defined as the most sustainable material in this research with a score less than 1 , it is admissible for producing based on "Peng" research in 2014. So the culture of using these kinds of materials should be encouraged in society.

\section{References}

(1) Oscar Ortiz a,b, , Francesc Castells a, Guido Sonnemann, Sustainability in the construction industry: A review of recent developments based on LCA, Journal of Construction and Building Materials 23 (2009), pp 28-39

(2) Gonzalo ferenandez - sanchez, Fernando rodriguiz - lopez , A methodology to identify sustainability indicators in construction project management - Application to infrastructure projects in Spain, journal of ecological indicators 10 ( 2010 ), pp : 1193-1201Mohammad Djavad Saghafi et al.2010

(3) Mohammad Djavad Saghafi, Zahra Sadat Hosseini Teshnizi , Recycling value of building materials in building assessment systems, Energy and Buildings 43 (2011), pp : 3181-3188

(4) Elisa Franzonia, Materials selection for green buildings: which tools for engineers and architects? , 2011 International Conference on Green Buildings and Sustainable Cities, Procedia Engineering 21 (2011), pp: $883-890$

(5) Eva Krídlová Burdová a, Silvia Vilčeková, Energy performance indicators developing, Energy Procedia 14 (2012), pp: 1175 - 1180

(6) Ogur Ekincioglua, Asli Pelin Gurguna, Yasin Enginb, Muhittin Tarhanb, Sezgi Kumbaracibasib , Approaches for sustainable cement production - A case study from Turkey, Energy and Buildings 66 (2013), pp: 136142

(7) Emad S. Bakhoum and David C. Brown, Developed Sustainable Scoring System for Structural Materials Evaluation, Journal of construction management engineering 138 (2012), pp: 110-119 
(8) Chen J.J, Chambers D, Sustainability and the impact of Chinese Policy Initiatives upon Construction, Construction management and Economics 17 (1999), pp: 679-688

(9) Peter O. Akadiri, Paul O.Olomolayie, Development of sustainable assessment criteria for building materials selection, emerald ECAM19, 6(2012), pp: 666-687

(10) Deborah N. Huntzinger a, Thomas D. Eatmon, A life-cycle assessment of Portland cement manufacturing: comparing the traditional process with alternative technologies, Journal of Cleaner Production 17 (2009), pp: $668-675$

(11) Li-yin Shen a, Vivian W.Y. Tamb, Leona Tamc, Ying-bo Ji, Project feasibility study: the key to successful implementation of sustainable and socially responsible construction management practice, Journal of Cleaner Production 18 (2010), pp: 254-259

(12) U.G. Yasantha Abeysundara a, Sandhya Babel b, Shabbir Gheewala, A matrix in life cycle perspective for selecting sustainable materials for buildings in Sri Lanka, Building and Environment 44 (2009), pp: $997-$ 1004

(13) Rayna Essa, Chris Fortune, Pre-construction evaluation practices of sustainable housing projects in the UK, ECAM 15, 6. 2008, pp: 514-526

(14) H.Wallbaum, Y.Ostemeyer, C.Salzer, E.Escamilla, Indicator based sustainability assessment tool for affordable housing cinstruction technologies, Elsevier journal of Ecological indicators 18 (2012), pp 353-364

(15) Liyin shen, M.ASCE,Yuzhe Wu, and Xiaoling Zhang Ph.D ,key assessment indicators for the sustainability of infrastructure projects, journal of construction engineering and management, june 2011 , pp : 441-451

(16) Gypsum Manufacturing, Emission Factor Documentation for AP-42, section 11.16, July 1993

(17) Satheeshbabu.S,Life Cycle Assessment of Cellular Lightweight Concrete Block - A green Building material, Journal of environmental Technology and Management (1) 2010 , pp: 69-79

(18) Emission Factor Documentation for AP-42, Section 11.3, Brick and structural clay product manufacturing (Final Report), For U. S. Environmental Protection Agency Office of Air Quality Planning and Standards Emission Factor and Inventory Group , August 1997

(19) Co2 Emission, More sustainable concrete by using Mecalithe, July 2014, PP: 1-12

(20) p.vaden Heede ,N.De Belie, Environmental impact and life cycle assessment ( LCA ) of traditional and "green " concrete : Literature review and theoretical calculation, Elsevier journal of cement \& concrete composites (2012), pp : 431-442

(21) World's steel association, Steel's contribution to a low carbon future, world steel position paper, June 2014

(22) Bin Zhang a,b, Zhaohua Wang a,b, Jianhua Yin c, Lixia Su, CO2 emission reduction within Chinese iron \& steel industry: practices, determinants and performance, Journal of Cleaner Production 33 (2012), pp:167-178

(23) Luisa F.Cabeza a, CamilaBarreneche a,b, LaiaMiró a, JosepM.Morera c, Esther Bartolí c, A.InésFernández, Low carbon and low embodied energy materials in buildings:A review, Renewable and Sustainable Energy Reviews 23(2013), pp: 536-542

(24) Yahya Jani, William Hogland, Waste glass in the Production of cement and concrete - a review ,accepted manuscript on Journal of Environmental Chemical engineering 310 ( 2014)

(25) B.V. Venkatarama Reddy, K.S. Jagadish, Embodied energy of common and alternative building materials and technologies, Energy and Buildings 35 (2003), pp: 129-137

(26) Iran Energy balance sheet of 2012, Power and Energy Affairs, Macro planning power and energy office 2013, Part 9-11-1 , Energy demand and supply optimization tables, page 264 (Cement Tables)

(27) Iran Energy balance sheet of 2012, Power and Energy Affairs, Macro planning power and energy office 2013, Part 9-11-1 , Energy demand and supply optimization tables, page 266 ( Steel Tables)

(28) D.Z. Li, H.X. Chen, Eddie C.M. Hui, J.B. Zhang, Q.M. Li, A methodology for estimating the life-cycle carbon efficiency of a residential building, Building and Environment 59 (2013),pp: 448-455

(29) Christian Meyer, Concrete Materials and Sustainable Development in the United States, Columbia University (2011), PP: 1-10 
(30) Brick, Benchmark energy consumption in production processes, Institute of Standards and Industrial Research of Iran, Standard number 7965, first revision, 2012

(31) Iran Energy balance sheet of 2012, Power and Energy Affairs, Macro planning power and energy office 2013, Part 9-11-1 , Energy demand and supply optimization tables, page 263 (Gypsum Tables)

(32) Iran Energy balance sheet of 2012, Power and Energy Affairs, Macro planning power and energy office 2013, Part 9-11-1 , Energy demand and supply optimization tables, page 264 (Lime Tables)

(33) Iran Energy balance sheet of 2012, Power and Energy Affairs, Macro planning power and energy office 2013, Part 9-11-1 , Energy demand and supply optimization tables, page 266 (Glass Tables)

(34) Shridhar Kumbhar a,b, Nitin Kulkarni a,c, Anand B. Rao a and Bakul Rao , Environmental Life Cycle Assessment of Traditional Bricks in Western Maharashtra, India , 4th International Conference on Advances in Energy Research 2013, ICAER 2013 , Energy Procedia 54 ( 2014 ) , pp: 260 - 269

(35) Traditional Gypsum production plan, Budget and Planning office of Finance and banking facilities, 2006

(36) Preliminary Feasibility Report of Industrial Lime production, Research Department of University of Kerman, Iran Small Industries \& Industrial Organizations, 2007

(37) Best Practices of the Natural Stone Industry Water Consumption, Treatment, \& Reuse, The University of Tennessee Center for Clean Products, September 2008

(38) A.Adib,S.Naziri,F.Montekhab,M.Vaghefi, Comparing of lightweight insulating concrete with saving energy approach, $1^{\text {st }}$ international Conference of Non-permeable concrete in Drinking water storage tanks, Gilan,Iran, February of 2012

(39) Manufacture of any kind of brick in kiln shuttle, Budget and Planning office of Finance and banking facilities, 2006

(40) Economic estimates of Light Concrete Block plan with a capacity of $100 \mathrm{~m}^{3}$, Budget and Planning office of Finance of En Bank of Iran, 2007

(41) Portland Cement Manufacturing,Emission Factor Documentation for AP-42, Section 11.6, Final Report, May 1994

(42) Iron and Steel Manufacturing, Emission Factor Documentation for AP-42, Section 12.5, October 1986

(43) Emission Factor Documentation for AP-42, Section 11.12 Concrete Batching, For U. S. Environmental Protection Agency Office of Air Quality Planning and Standards Emission Factor and Inventory Group , June 2006

(44) National Pollutant Inventory Emission Estimation, Technique Manual for Plasterboard and Plaster Manufacturing,Version 1.3 , July 2012

(45) Emission Factor Documentation for AP-42, Section 11.17 Lime Manufacturing (Final Report), For U. S. Environmental Protection Agency Office of Air Quality Planning and Standards Emission Factor and Inventory Group, February 1998

(46) Ceramic Products Manufacturing, Emission Factor Documentation for AP-42, section 11.7, Supplement B, July 1996

(47) Emission Factor Documentation for AP-42, Section 11.15 Glass Manufacturing, For U. S. Environmental Protection Agency Office of Air Quality Planning and Standards Emission Factor and Inventory Group , October 1986

(48) Statics of Labor Force, Statistical Center of Iran, Report from 2005 to now, https://www.amar.org.ir/english/Statistics-by-Topic/Labor-force\#2222531-meta-data

(49) Analytical report cooperatives metal industry, Ministry of Cooperatives, Labor and Social Welfare, March 2012.

(50)Ready-mixed concrete Production Plan, Ministry of Cooperatives, Budget and Planning office of Finance and banking facilities, 2006.

(51) Building Stones researches, Non-metallic mineral products, Research Center of Iran Parliament, 2012

(52) Cliff F.Grimes, Productivity document at http://www.accel-team.com, Last online: 2015/7/2

(53) Assessment of cumulative cost impact for the steel industry (final report), Centre for European Policy Studies \& Economisti Associati, June 2013. 
(54) Vivian W. Y. Tam, Economic ComparISOn of Concrete Recycling: A Case Study Approach, Griffith School of Engineering, Griffith University, Australia, QLD 9726, pp:1-18.

(55) Statics of Supply and Demand Units in Iran, Statistical part of Ministry of Industry, mind and trade, Report Date : 18/05/2014, http://en.mimt.gov.ir/web_directory/13625-Case-Reports.html

(56)Maria Chiara Bignozzi, Sustainable cements for green buildings construction, International Conference on Green Buildings and Sustainable Cities 2011, pp 915 - 921.

(57)Bin Zhang a,b,Zhaohua Wang a,b, JianhuaYin c,Lixia Su, CO2 emission reduction within Chinese iron \& steel industry: practices, determinants and performance, Journal of Cleaner Production 33 (2012),pp:167-178.

(58)Ali Hasanbeigi a, William Morrowa, Jayant Sathaye a, Eric Masanet a,b, Tengfang Xu, A bottom-up model to estimate the energy efficiency improvement and $\mathrm{CO} 2$ emission reduction potentials in the Chinese iron and steel industry, Journal of Energy 50 (2013), pp: 315-325.

(59)Peng Wu a,n, Bo Xia b, Xianbo Zhao, The importance of use and end-of-life phases to the life cycle greenhouse gas (GHG) emissions of concrete - A review , Renewable and Sustainable Energy Reviews 37 (2014), pp: 360-369.

\section{Copyrights}

Copyright for this article is retained by the author(s), with first publication rights granted to the journal.

This is an open-access article distributed under the terms and conditions of the Creative Commons Attribution license (http://creativecommons.org/licenses/by/4.0/). 